\title{
Analysis of Reasons for The Absence of Aesthetic Education in University Education and Exploration of Aesthetic Education's Future
}

\author{
Lina Ma \\ Xing Zhi College of Xi'an University of Finance and Economics \\ Xi'an, Shaanxi, China \\ 634068303@qq.com
}

\begin{abstract}
Keywords: Aesthetic Education; University Education; Missing Reason; Exploration of Aesthetic Education's Future
\end{abstract}

\begin{abstract}
As one of the four educations of morality, intelligence, physique and aesthetic, aesthetic education is the key measure and call for all-round quality education in China. University education aims at fostering "perfect man", who is a cultivated and sensible person. Aesthetic education is to cultivate college students' aesthetics, shape their sound personality and beautiful soul, so as to improve their sentiment and make them become a sound college students with all-round development of morality, intelligence, physique and aesthetic. However, in college education aesthetic education is still in the absence situation because of some factors. We need to recognize and analyze the reasons for these deficiencies to find out and develop the future of aesthetic education in university education.

University education influences people's values, career, way of thinking, critical spirit, persistent willpower, professional knowledge and so on. Jaspers said in "what is education", education is nothing more than the spiritual and physical exchanges between human beings, including the imparting of knowledge, the understanding of the connotation of life, the standardization of volitional behavior, and the teaching of cultural heritage to the younger generation through the function of cultural transmission, so that they can freely generate and inspire their free nature. Educational activities are concerned with how to maximize the mobilization and realization of human potential, and how the internal spirituality and possibilities of the full generation, in other words, education is the education of the human soul, rather than the accumulation of rational knowledge. [1]

Education is the education of the human soul, not the accumulation of knowledge. Therefore, university education should bear multiple values. University is the spiritual home of scholars, the foundation of their studies and careers, the cornerstone of their adulthood and happiness, and the place where they grow up. Therefore, aesthetic education in university education naturally edify the sentiment of university students, improve their personality, cultivate their aesthetic, improve the composition of their studies. However, the current understanding of university students' aesthetic education is still in the absent position, so we need to explore the reasons for its absence to find the future of aesthetic education in university education.
\end{abstract}

\section{The Growth of Mercenary Social Ethos}

In the 21 st century, China has shown itself an economy taking off rapidly country on the world stage. The Chinese people have been liberated from the concept of savings, and have gradually paid attention to the impact of investment and consumption on China's economy, as well as their own interests. The Chinese people have been liberated from the concept of saving and have gradually focused on the impact of investment and consumption on China's economy, as well as on their own interests. From a sociological point of view, consumption is not only individual and family behavior, but also group behavior. People consume something not only to satisfy their basic needs, but also to confirm their social identities and fulfill their meanings. [2]

When the Chinese people said goodbye to the era of product shortage and entered the era of economic development, along with the change of people's broad consumption concept and the 
pursuit of material supremacy, it resulted in the abnormal development of social economy and morality, and made people become a slave to seek benefits and even money supremacy. People's pursuit of material life is not only to meet basic needs, but also to satisfy their own value and status through consumption, and even consume goods far beyond their ability. On the contrary, the consumption of spiritual and cultural products is still in the primary stage of spiritual consumption, the understanding of spiritual and cultural consumption only stays in leisure, entertainment, the pursuit of luxury houses, luxury cars, overseas tours and other life.

Contemporary economic and technological development not only gave birth to the weakness between human feelings, but also developed the importance of advertising to guide people's consumption choices. Advertisements are full of not only the latest, best and most expensive consumer products, but also the most comfortable, modern and wealthy life to the public, and tell them that these are worth pursuing and owning. The growth and formation of these social ethos, are affecting the understanding of college students for the concept of consumption, they live in the campus and between the campus, receiving the latest trend of information and fashion life information, the pursuit of ignoring the gap between urban and rural areas, the gap between rich and poor, the age gap in consumer goods, beyond their load. And understanding. As in recent years, media coverage of university students' naked loan incident has been reported. These college students are influenced by the social climate of materialism and the pursuit of luxury goods or spending beyond their means. These college students also have a lack of understanding of self-love. The pursuit of virtue and beauty is becoming weaker and weaker in college students' consciousness. The ability to judge the beauty and ugliness of things is lost and ignored. They are more willing to pursue material things, satisfy the heart of comparison and form a disguise of themselves. And the inner fullness is very valuable to the college students who are receiving higher education.

Such a social atmosphere is undergoing a tug-of-war with college students who receive aesthetic education. Their relaxed and comfortable material pursuit makes them unconsciously ignore how important aesthetic education is for them to form sound and rich moral character, and how precious aesthetic education is for them to become a self-sufficient person in the future. Therefore, when we condemn children today for losing the pursuit of moral character, love for others, and even the ability to love themselves, we may ask ourselves, as their elders, the guide of their lives, for the future society's protagonists, whether we provide them with a good moral. Environment, a life that can be enriched without additional material.

\section{The Influence of Employment Oriented Teaching Philosophy.}

From the early twentieth century, aesthetic education was put forward. Until 1990s, aesthetic education was gradually taken seriously. State documents and decrees also highlight its status. The outline of China's education reform and development promulgated in March 1993 pointed out: We should raise our awareness, give full play to the role of aesthetic education in education and teaching, and carry out various forms of aesthetic education activities in accordance with the different conditions of schools at all levels and in various types. At the National Art Education Conference held in November 1996, Liu Bin, deputy director of the former State Education Commission pointed out that Aesthetic education (including art education) is an integral part of China's education, and it is very important in the whole education. Aesthetic education plays an important role in all aspects of morality, intelligence and physique, which can not be replaced by other disciplines. [3]

Entering the twenty-first century, aesthetic education is still being put forward. In September 2015, the general office of the State Council issued the opinions on Comprehensively Strengthening and improving the aesthetic education in schools. The paper points out that aesthetic education is still a weak link in the whole educational undertaking. The course of aesthetic education in colleges and universities should rely on the advantages of relevant disciplines and local educational resources, expand the contents and forms of education, guide students to improve their personality, strengthen students' awareness of cultural subject and cultural innovation, and enhance students' sense of responsibility and mission to inherit and carry forward Chinese excellent culture and art. 
Two years have passed. The change of aesthetic education in colleges and universities is that students have received the influence of public elective courses such as art appreciation, film and television appreciation, body art, etc. In some professional courses, they have learned the relevant aesthetic theories and obtained the credits of practical courses. However, students will still be troubled by some problems. "What does learning have to do with my major? Why should I waste time in these courses? These beautiful things are too tall, they are not so grounded." Therefore, changing the school and students' cognition of aesthetic education itself is the way that aesthetic education can develop in colleges and universities, enrich students' horizons, realize their unlimited possibilities, and enjoy the good vision of college life.

With the difficulty of employment in China, the employment of college graduates has gradually shifted from seller's market to buyer's market. In order to improve the employment rate of schools, meet the expectations of students and parents for schools, schools also have to consider the impact on students' employment when setting up disciplines. Employment-oriented teaching concepts continue to be applied in teaching, and colleges and universities have gradually become a kind of training schools to train students in various professional skills, so that students can obtain employment when employers favor. Aesthetic education is equally important to cultivate students' integrity, sense of responsibility and courage to take on the good qualities of being willing to bear hardships.

Graduates with certificates of several professional skills, skills courses and aspirations to a light, high-paying job begin to wonder why they are rejected when they are frustrated and tortured by various human problems while seeking a job. Who can answer questions when they can't work efficiently with the team or when others can't understand them. Therefore, the pursuit of Employment-oriented Teaching concept can not provide students with a high-quality job in the future, and aesthetic education is equally important to them. This requires colleges and universities to provide certain funds and teachers for aesthetic education, give aesthetic education a certain degree of attention, cultivate students' aesthetic and aesthetic perception ability, so that they can distinguish good from evil, beauty and ugliness, enrich and exercise their own body and mind. how can't we resist the tide of employment, how can't we face the frustration of life.

\section{Academic Performance Is the Only Standard}

Since the end of the 20th century and the 21 st century, China's rapid economic development, and the implementation of family planning policy, so that children born after the 1980s have experienced China's historical turning point in this period, whether material or educational, they are experiencing changes. Parents experienced childhood shortage of material, life shortage, and constantly meet the needs of children with material, eat well, dress well, well used, which becomes the happiness of the growth of this generation of children. Parents give their children selfless love at the same time, but also to the children given the hope of the family with a heavy burden. Academic performance is the most important. Entering a good university, finding a good job, only in this way you can gain a foothold in society.

This generation of children not only wants to realize their own life, but also carries their parents' life. Parents provide them with the best material life possible to achieve good results, but ignore the importance of their children's spiritual growth. As Mr. Lin Yutang said, "It is more important for us to cultivate our feelings and feelings than to educate our thoughts." [4] Limiting activities and entertainment that are not related to schoolwork to achieve what they call success make communication between children and their parents not smooth. The tension is contradictory, and the family can not understand and communicate with each other. The value of this quick success and instant benefit has always affected and established the criterion of children's value judgment. Therefore, useful and useless concepts have deep-rooted values in children's judgment standards. They use this set of adult will to measure their own behavior and the need for education. They ignore the aesthetic education for their physical and mental growth, the importance of aesthetic education for their healthy personality. In this way they become frustrated and can not be optimistic. When encountered difficulties, they want to escape. 


\section{Pragmatism Purpose of Learning}

Mr Zhu Guangqian once said in his book Talking about Beauty that we have three attitudes towards an ancient pine: practical, scientific and aesthetic. There are many things in the same thing, and there are many kinds of phenomena. [5] The three attitude represents our different state of mind and attention.

Nowadays, freshmen are always able to get information about their major from their predecessors, including teachers, courses, certificates and other issues. These "professional characteristics" attract them more than the school regulations, and are regarded as the magic weapon to spend four years smoothly. During these four years, they have followed these "advice" as if they were holding the secret books of customs clearance. Which courses are not important, which courses must be given high marks, and which certificates can help them find jobs. These are among the top priorities for students to have a good four-year college life. They are busy getting certificates in classes and training, fretting about why they have to take these classes, going in and out of associations, eager to meet all the elders, and rushing to say goodbye without even a good campus love experience. Among the graduates, there is no lack of lamentation that four years of college life passed so quickly, so confused, and they did not feel his good, ignored his care, did not cherish his opportunities. After leaving university for many years, when they look back and reflect the feeling ideals and youth they should have during college life, the understanding of the university is becoming clearer and clearer.

These erroneous understanding and university life and pragmatic belief in the purpose of learning created a gap between students, ignored the differences and ignorance before they go to school. They are more concerned about their future than their peers. The alienation of human nature, the expansion of self-consciousness, the lack of concern and understanding of others, vicious competition and contrast, and the pursuit of pragmatism have led to their unequal and unbalanced values, unable to appreciate each other, and gradually drifting away from their own "examoriented" education. Therefore, the aesthetic education for college students is to get them out of the pragmatic purpose of learning, to view and spend the best years of life with more thinking and aesthetic appreciation, to interact with students with more appreciative eyes and soul, to compete and learn, so that they can relive and enjoy the journey of life time after time. They can become the strong in life, can recognize others' strong, also can appreciate themselves' good. As Mr Zhu Guangqian said: in the activity of doing something, man is the slave of the environment; in the activity of doing nothing, man is the master of his own mind. Beauty is the most valuable aspect of things, and aesthetic experience is the most valuable aspect of life. [6]

Based on the above analysis of aesthetic education in college education, I believes that there are several ways to change:

1. carry out the construction of teaching staff for aesthetic education in colleges and universities.

2. establish a complete and specific evaluation system for the investigation of aesthetic education.

3. through the study of aesthetic education courses, we can build students' cognitive ability toward beauty.

4. let students feel emotional interaction in words and deeds.

5. analyze and guide social phenomena and form the ability of students to judge independently.

6. communicate with parents, and reach consensus on the aesthetic education of students.

Aesthetic education was raised in twentieth century. It became especially precious and important in twenty-first century. While imparting knowledge to students, colleges and universities should also care for their inner growth and change, give them the ability to stand on their own feet, and at the same time, give them the ability to perceive beauty. So that they can retain an innocence and beauty in this society of material wealth and spiritual deficiency. Four years' college life is both beautiful and short. It is also the best life in life. Borrowing Mr. Zhu Guangqian's placard in the Alps Valley, "go slowly, enjoy it!" to end, isn't it the same for children's lives? 


\section{References}

[1] Jaspers, K., what is education [M], Zou Jin, Translation. Beijing: life, reading, new knowledge triple Bookstore

[2] X.S.Lin and Y.Zhang. Institutional change and consumption stratification: an analysis perspective of consumption inequality [J]. Journal of Lanzhou University (SOCIAL SCIENCE EDITION), 2014,1:10.

[3] B.Tang. The evolution of contemporary aesthetic education in China [J]. Journal of Southwestern Normal University 2000,9:116.

[4] Y.T.Lin. The art of life [M]. Shenyang: Volumes Publishing Company, 2013.6,50.

[5][6] G.Q.Zhu. Tan Mei [M]. Shanghai: East China Normal University press, 2012.7:1,6 